\title{
A curriculum for action in the community and intercultural citizenship in higher education ${ }^{\dagger}$
}

\author{
Melina Porto $^{\mathrm{a} *}$ and Michael Byram ${ }^{\mathrm{b}}$ \\ ${ }^{a}$ Facultad de Humanidades y Ciencias de la Educación (School of Humanities and Sciences of \\ Education), Instituto de Investigaciones en Humanidades y Ciencias Sociales (Institute of \\ Research in the Social Sciences and the Humanities), Universidad Nacional de La Plata and \\ CONICET (Consejo Nacional de Investigaciones Cientificas y Técnicas), La Plata, Calle 33 No. \\ 417, La Plata, Buenos Aires 1900, Argentina; ${ }^{b}$ School of Education, University of Durham, Leazes \\ Road, Durham DH1 1TA, UK
}

(Received 1 April 2015; accepted 10 July 2015)

The purpose of the project described here is to demonstrate how the introduction of subject matter and principles from citizenship education into foreign language education combines objectives from both in order to give meaning to language education on the one hand and extend citizenship education beyond a focus on the local and the national on the other. In doing so, the educational aims of foreign language teaching - as well as its instrumental purposes - can be met and the scope of citizenship education is extended to include intercultural citizenship. The project was located in Higher Education in Argentina, where 76 students were learning English, and in Britain, where 23 students were learning Spanish. It focused on human rights violations during the football World Cup that took place in Argentina in 1978 during a period of military dictatorship and it was carried out in 2013 during a fourth-month period. Data were collected then and comprise documentary data (posters, PowerPoints, videos, etc.) and conversational data (online communication between the Argentinian and British students using Skype). This article describes the processes of the project and the ways in which students reacted, particularly the Argentinian students who felt personally involved, and demonstrates how the combination of language and citizenship education, when given the additional viewpoint of an insider and outsider perspective, leads to significant developments in learners' lives: an identification with a transnational group and perspective, and a willingness to become directly and critically involved in action in the community.

Keywords: intercultural citizenship; foreign language education; criticality; civic involvement; human rights; higher education; Argentina

\section{Introduction}

The starting point for the teachers in the project described in this article is that language teaching has educational as well as instrumental purposes. Whether referred to as 'foreign', 'second' or 'world' language teaching, most of this activity throughout the

\footnotetext{
*Corresponding author. Emails: melinaporto@conicet.gov.ar; M.Porto@uea.ac.uk

†This article was written as part of Dr Porto's Postdoctoral Programme in Human and Social Sciences (2014-2015) from Universidad de Buenos Aires, Argentina.
} 
world is carried out in schools and universities and most often within obligatory education. The focus of contemporary language teaching in schools and universities, from the moment it began to replace the teaching of classical languages in the nineteenth century in the European and North American tradition, has swung between the humanist-inspired development of the person (Bildung) and a utilitarian preparation of learners for their (working) life, after their education is over. 'Communicative language teaching' pushed language teaching into the utilitarian direction and, in modified versions, is now dominant in most teaching situations.

Without in any way denying the instrumental value of learning one or more languages, the project described here is located in a perspective which emphasises that language teaching can contribute to general education, to the development of individuals and to the evolution of societies. It does so by borrowing from 'education for citizenship' (Arthur, Davies, \& Hahn, 2008; Osler, 2012; Osler \& Starkey, 2006; Qualifications and Curriculum Authority, 1996) and by drawing upon practices of 'intercultural communicative language teaching' (Byram, 1997; Liddicoat \& Scarino, 2013). At the same time, it extends the scope of citizenship education beyond the notion of citizenship of a (nation) state and into intercultural citizenship (Byram, 2008, 2012).

The project we shall describe is one of a network of projects in the Americas, Europe and Asia (Byram, Golubeva, Han, \& Wagner, in press), all of which link groups of learners in two or three countries around a topic of social import - for instance environmental issues - which they explore in a comparative methodology, through interaction across the Internet. As a consequence of their cooperation, they plan and implement civic action in their own sociopolitical milieu, action through which they try to bring change in the world they inhabit, usually on a very small but nonetheless significant scale. The project described here brought together university-level learners of English in Argentina and of Spanish in Britain.

\section{Theoretical foundations in language education and citizenship education combined}

\section{The complementary objectives of language teaching and education for citizenship}

The creation of state-supported education systems in the European/North American tradition in the nineteenth century had a variety of causes and purposes, which included the creation of a citizenry identifying with and loyal to the state (Gellner, 1987; Hobsbawm, 1992). This remains a significant function within this education tradition. It was also exported to other parts of the world through colonialism, and adopted in postcolonial times as a means of supporting the evolution of new states. Against the background of this traditional function of education, citizenship education, in varied but related forms, has gained a renewed importance as a reaction to globalisation and an apparent lack of interest in political participation among young people (Barrett, 2012), remaining however largely focused on the local and the national, not the international.

When foreign language teaching considers its educational function - as well as its instrumental purposes - its aims begin to coincide with some of the aims of contemporary citizenship education (Byram, 2012). At the same time, it becomes evident that limitations in each can be remedied by combination with the other, as Byram argued in one of the foundation documents for this project (2008, pp. 155-219). Citizenship education and interculturally oriented language education share an interest in developing learners' competences in analysis, cooperation and knowledge about societies and the sociopolitical environment. Citizenship education, in the versions we focus on, aims to lead learners to act as citizens 
of their state as a direct consequence of their learning and simultaneously with it. For example in 'Project Citizen' in the USA, learners are told that

This project is intended to help you learn how to express your opinions, how to decide which level of government and which agency is most appropriate for dealing with the problem you identify, and how to influence policy decisions at that level of government. (Center for Civic Education, 2008, p. 1)

In the UK, the Crick Report identified one of three strands of citizenship education as:

Community involvement

Pupils learning about and becoming helpfully involved in the life and concerns of their communities, including learning through community involvement and service to the community.

(Qualifications and Curriculum Authority, 1996, p. 40)

In citizenship education it is thus intended that learners should become involved in community action simultaneously with their education, whereas in language teaching in schools and universities this characteristic is not evident and the focus is rather on preparing learners for life after they leave education. On the other hand, language teaching can turn learners' attention to otherness, to groups of people who speak the language being learnt. Language teaching goes beyond the focus on 'us' and 'our state' or 'our community' which is evident in policies of education for citizenship. Traditionally, the others are people who speak the language as first language, but increasingly it refers to other groups who use a lingua franca, especially if the language is English. ${ }^{1}$ In short, citizenship education is 'nationally' orientated, whereas foreign language education is 'internationally' or 'interculturally' orientated.

The purpose of the project was, then, to combine language and citizenship education, and to create transnational communities in order to implement the principles enunciated here and elaborated elsewhere (Byram, 2008). We searched for a term which was relatively neutral, given the heated discussions around other terms such as 'global' or 'intercultural' or 'transcultural'. There has for example been a debate in Germany about the weaknesses of the term 'intercultural' and the need to substitute 'transcultural', a debate which Bredella (2010) argues is an empty one. 'Transnational' is also a term favoured by Risager (2007). In the project, such transnational communities would operate on a topic, leading to civic action or action in the community.

\section{Identification with a transnational community}

We wanted our learners to identify with their transnational community, at least for the duration of the project. Norton (2000), Norton and Toohey (2011), Ros i Solé (2004, 2007, 2013), Ros i Solé and Fenoulhet (2011) and Tsui (2007), among many others, have addressed the topic of social identifications in L2 learning. For instance, Block (2007) reviews the empirical research on the impact of language teaching and learning on learners' identifications and argues that, in the ordinary language classroom, there is no likelihood of learners' existing identifications with their own country being changed, but we hoped that, for the duration of the project, learners would identify as one group, as one transnational community.

The question of social identification and the acquisition of social identities has been much researched, starting with the work of Tajfel (1982) and is well summarised by Ellemers' discussion of the group-self: 
The group self (instead of the individual self) can guide people's behaviors when they realize they are part of the group (cognitive self-definition) or when they are subjectively committed to the group (emotional self-involvement). These two do not necessarily go together. The group self not only determines how people respond to others but also has an impact on how they prefer others to respond to them. The desire to be valued by others and included in groups is a basic human need. However, this does not imply that people relinquish their feelings of individual uniqueness ... (Ellemers, 2012, p. 848)

We intended that learners would work cooperatively on a common concern. The importance of working together as one of the conditions for identification was first noted by Allport (1954/1979), who argued that intergroup relations - such as might exist between an Argentinian group and a British group of learners in our project - are often affected by prejudice, but that to overcome prejudice it is not enough merely to bring two groups into contact with each other. If prejudice and stereotype are to be overcome, then groups working together should have equal status and common goals and be involved in cooperative activity which is supported by the relevant authorities. As a consequence, we put together students who were of similar age, educational experience and at similar levels of foreign language competence. They worked together on a topic of common interest which was supported by the authority of its taking place as part of the regular curriculum in their foreign language lessons.

Thus, our overarching research question was whether, by combining foreign language education with education for citizenship, learners would identify with a transnational community and become involved in action in the community. This was one fundamental starting point.

A second impetus came from the fact that our model of language teaching for intercultural communicative competence (Byram, 1997) also introduced the notion of criticality. In the model in question, one aspect of intercultural competence is defined as critical cultural awareness, that is, an ability to evaluate critically the perspectives, practices and products in one's own and other cultures and countries. We intended that students' involvement in the community would be critical in this sense. We then turned to Barnett (1997) for a more nuanced view of criticality. Barnett identifies three domains in which criticality should operate:

- propositions, ideas and theories - that is, what learners learn about the world (in formal education what they learn in their subjects),

- the internal world, the self, a form of critical thought that is demonstrated in critical self-reflection - that is, what learners think about themselves as individuals, and

- the external world, a form of critical thought that is demonstrated in critical action that is, what learners do as a result of their thinking and learning.

He also identifies four levels or degrees of criticality - increasingly complex and deep:

- critical skills - reflexivity - refashioning of traditions - transformatory critique.

At the first level, the emphasis is on skills of learning how to be critical. At the second level the skills are applied to the knowledge learners have acquired, to their own selves and to the world. At the third level, the criticality leads to change, that is, modification of what has so far been accepted as common sense in knowledge, in oneself, in what we do in the world. At the fourth level, the change is more radical, that is, it is not just modification of what is 
common sense or taken for granted, but overturns this and develops something new, a 'critique-in-action' and a 'collective reconstruction of the world'.

Our research question could now be formulated as:

Does a course which combines language teaching and citizenship education lead learners to identification with a transnational community, to critical engagement with the communities in which they live, and to action in their communities?

\section{Overview of the teaching and learning}

\section{Background information}

In 1978, the football World Cup took place in Argentina. This was in the middle of a period of military dictatorship from 1976 to 1983 during which anyone suspected of being against the government was abducted and tortured. Thousands of young people and children 'disappeared' at this time - and lost their true identities as they were raised by people loyal to the regime - but their mothers began to gather peacefully in Plaza de Mayo in Buenos Aires clamouring for their children. They wore white scarves on their heads and were soon known of throughout the world. At this time, the World Cup was used by the military forces to distract attention from the human rights violations and the killings that were taking place. Since then, the mothers have continued to be active and have recovered 114 children by encouraging those in doubt about their identity to take a blood test. The past is still present and the teachers in this project decided to suggest this topic to the students, who, aged around 20 years, were born after democracy was restored in 1983, and for whom then it was an unfamiliar past.

\section{Participants}

The project took place over a period of 16 weeks between September and December 2013 and was integrated into a course of English Language in Argentina and Spanish Language in Britain. In Argentina, there were 76 second-year undergraduates studying English at a national university, all future teachers and/or translators of English; they had level $\mathrm{C} 1$ in the Common European Framework of Reference. In Britain, there were 23 students (20 British, 1 Italian, 1 German and 1 Belgian), who were first-year undergraduates taking a Spanish Honours language degree. The students had level B2/C1 in the Common European Framework of Reference. All students were aged 18-22 years, 10 males and 89 females.

The English course in Argentina and the Spanish course in Britain had introduced the intercultural citizenship component described in this article for the first time in 2012 (see Porto, 2014). Up to then, the courses had been planned and taught predominantly as language courses with a linguistic focus. The project was a course requirement and the participants were informed of this new focus. The topic was clearly relevant for the Argentinian students because the dictatorship period is part of the recent history of their country, but less so for the British students, and here we shall focus on the Argentinian students. However, reflection logs written by students showed that both groups valued the project as an opportunity to interact with native speakers of the foreign language they were learning. Furthermore, the teacher of the British students was Argentinian herself who normally used material about the country as a springboard for language development, and thus the focus of the project was not a major departure from her usual work and what the British students were used to. 


\section{The teaching and learning process}

The project had four stages: introductory, awareness-raising, dialogue and citizenship. In the introductory stage, aimed at arousing curiosity about the topic through research skills and at exploring and reflecting on a historical cultural event of contemporary relevance, each group of students researched both the dictatorship and the World Cup, during lessons and also in their own time. They did not yet interact with the other group, although the same sources were used by both groups. They analysed documentaries, interviews, videos, magazines and newspapers, among other sources. For example, they found websites (abuelas.org.ar; desaparecidos.org/arg/victimas/), songs ('Mothers of the disappeared' by U2 and 'They dance alone' by Sting), films (youtube.com/watch? $\mathrm{v}=$ FU-JcRjGWFY) and media resources (iisg.nl/collections/tourism/images/d12-375.jpg; elhistoriador.com.ar/ index.php). The Argentinian students and their teacher also visited the Museo de Arte $y$ Memoria in the city of La Plata. Students in each country discussed ideas and prepared posters summarising the information gathered using Glogster, Prezi and other resources of their choice.

In the awareness-raising stage, students analysed the media representations of both the dictatorship and the World Cup in the print and other media of the time, with the following questions to guide their thinking (In English and Spanish for the Argentinian and British groups, respectively): What image of the Argentinian people is created from these materials? What representations and images did the media construct about the Military Junta in Argentina and in other countries? And about the 1978 World Cup? How do these representations and images influence the way you would approach a military officer, a former 'disappeared', a relative of a 'disappeared' or a footballer of those times? What might be the attitudes of young people like you towards the sporting event and the military government? After this analysis and reflection, they were encouraged to think of other instances around the world in which a sports event had been used to mask military, political or other issues. The aim of this stage was to critically analyse representations of the historical event constructed by the media and raise awareness of the power of the media in manipulating thinking and behaviours. It corresponds to Barnett's first level of criticality when students are developing their skills, in this case the skills of reading historical documents.

During the dialogue stage, we wanted students to apply their skills and to begin to reflect on their findings by encouraging them to talk to the other group, on the other side of the Atlantic, noticing similarities and differences in their perspective on the data. We hoped this would operationalise Barnett's notion of reflective practice in applying their skills to issues in the world. To stimulate this, they were given the task of designing a collaborative leaflet or poster in English and Spanish which would raise the awareness of people today about human rights violations during the World Cup in 1978. This was done in small groups of British and Argentinian students in Skype conversations and they were instructed to use English and Spanish on alternate days, to record their conversations and to upload them on the Internet. They used a variety of resources to create their leaflets and a wiki became a shared virtual classroom for the two student groups which they used, with email, to document the different stages and activities of the project and to communicate among themselves asynchronously.

One of the leaflets that the Argentinian and UK-based students designed in collaboration plays with different images (Figure 1). On the back panel of the leaflet is a headscarf worn by the mothers of 'the disappeared'. The image on the front panel plays with the original World Cup logo by introducing a skull instead of a trophy. The leaflet not only provides information about the sports event and the dictatorship, but it also offers a comparative and 


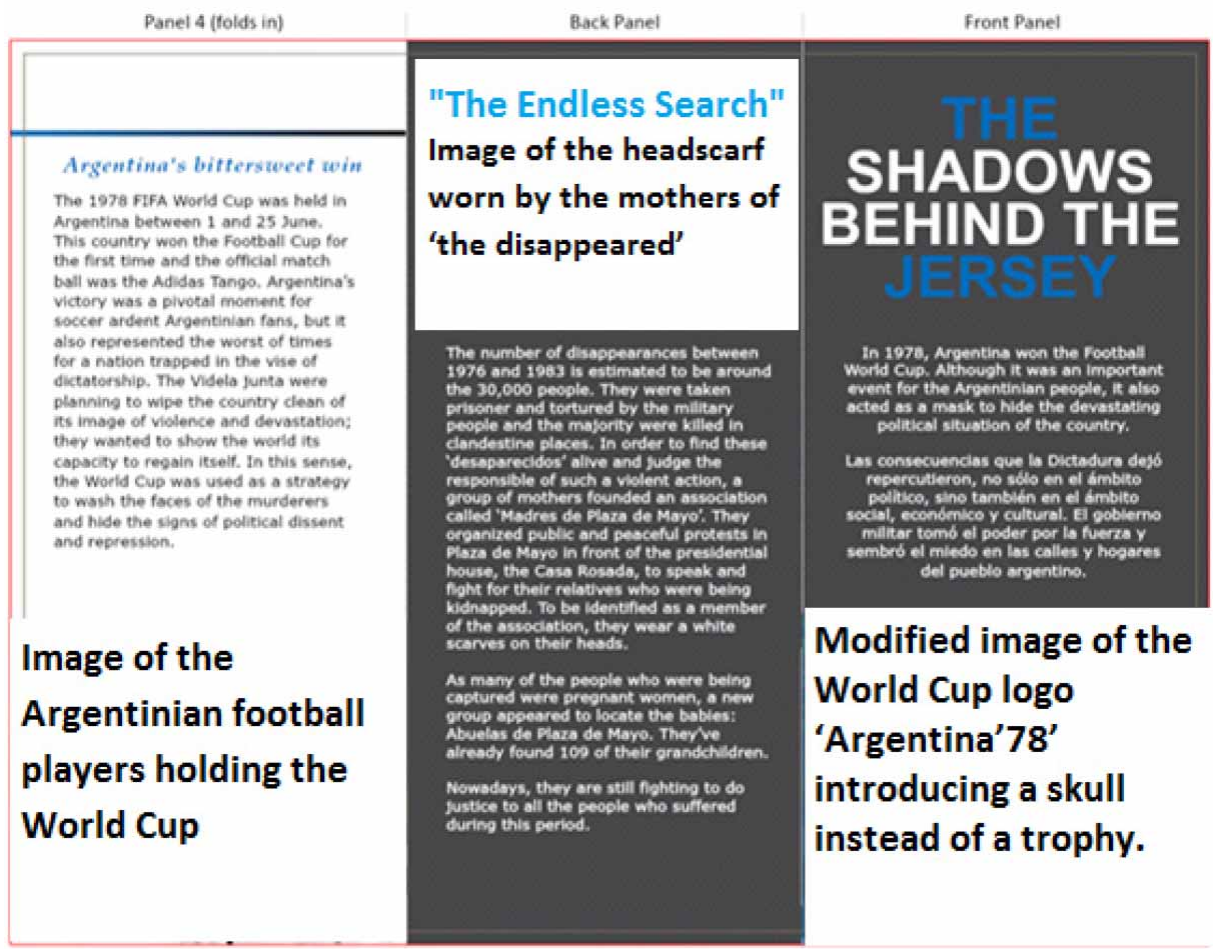

Figure 1. Extract from a collaborative leaflet by a group of Argentinian and British students. For copyright reasons, images have been eliminated from this leaflet.

critical perspective (evidence highlighted in italics) ('Argentina's victory was a pivotal moment for soccer ardent Argentinian fans, but it also represented the worst of times for a nation trapped in the vice of dictatorship').

Although both groups had been equally involved up to this point, the last of the four stages was the realisation of the citizenship dimension of the project for the Argentinian students only due to institutional constraints at the UK University at the time. They implemented an action in the community - a phrase they began to use themselves which might have an impact on their local communities. Now, they formed local groups, without their peers in the other country, and analysed the experience by writing reflection $\operatorname{logs}$ in the language they were learning. Examples of action in the community for the Argentinian students include:

- talking to family and friends and interviewing a neighbour;

- talking to passers-by in Plaza San Martín in La Plata;

- giving a talk and sharing posters and information with university students at the local School of Medicine;

- travelling $100 \mathrm{~km}$ to work with student teachers at a teacher training college on how to teach this historical period with primary school students;

- travelling $500 \mathrm{~km}$ to interview a 95-year-old man whose son had disappeared.

Here then we saw students with their action in the community realising what Barnett refers to as 'critique-in-action' and a 'collective reconstruction of the world'. 


\title{
The language teacher's perspective
}

The project took place in language lessons where teachers were concerned both with students' language development, for instrumental purposes, and with the educational value of the project. We saw above that one motivation for the students was the opportunity to interact with native speakers, still an important issue for learners whatever the theoretical debate on native speakers might say (Holliday, 2006; Houghton \& Rivers, 2013).

However, it was not our intention to chart students' language gains by systematic testing. The teachers relied on their informal observations, but above all on the importance of creating opportunities for a focus on content rather than form and the principles of Content and Language Integrated Learning (CLIL) (Coyle, 2007). CLIL is usually a matter of teachers of other subjects using a foreign language to teach their subject and Coyle (2007, p. 548) sums up the benefits of CLIL as follows:

\begin{abstract}
CLIL can and does raise learner linguistic competence and confidence; raise teacher and learner expectations; develop risk-taking and problem-solving skills in the learner; increase vocabulary learning skills and grammatical awareness; motivate and encourage student independence; take students beyond 'reductive' foreign language topics; improve L1 literacy; encourage linguistic spontaneity (talk) if students are enabled to learn through the language rather than in the language; develop study skills, concentration (learning how to learn through the language is fundamental to CLIL); generate positive attitudes and address gender issues in motivation; and put cultural awareness back on the agenda.
\end{abstract}

In this project however language teachers became themselves CLIL teachers and followed the principles of CLIL in the language classroom. The successes of CLIL are potentially transferable to the language classroom and, if space allowed, it would be possible to discuss how the principles were also in operation here. One comment from a student in her Autobiography of Intercultural Encounters (AIE), which will be explained below, will have to suffice to indicate the awareness among students of the linguistic benefits, but it is also important that her remarks are intertwined with other comments:

I think that interacting with a native speaker of the language you are learning is the best way to actually put in practice what you have learned about that language. It has also helped me realise what I have to improve. It really helped with my fluency and my communication ability, it made me realise how different and also how alike we can be even if we are from very far away points of the world. (Amalia, AIE)

As well as the attitude to native speakers, it is important to note that Amalia links, in one sentence, the language gains - 'helped with my fluency and my communication ability' and the critical insights into different perspectives which were the main focus of the project.

On the other hand, there was no imposition of language use. Although the teachers recommended that students use English and Spanish on alternate days, in fact they shuttled between different communities and contexts 'with the ability to negotiate the different discourses making each context' (Canagarajah, 2005, p. 32). For instance, one group negotiated the content, format and language of their collaborative leaflet by resorting to media sources in French and Italian, which they decided to translate into English. This occurred as the students were doing several things simultaneously: they were speaking Spanish and English, reading text in other languages (French, Italian, Spanish and English), translating text from one language into another, writing, and using digital resources and tools, in line with current developments in foreign language education (Hafner, Chik, \& Jones, 2013; Warschauer, Zheng, \& Park, 2013) and education more generally (Livingstone, 2012). 


\section{Data collection and analysis}

In order to answer our research question with its focus both on identification with the transnational group and on criticality, data were collected from various sources: recorded Skype conversations; chats in the wiki and Facebook, and email conversations; class discussions recorded on ipods and phones and uploaded to the wiki. There were 23 mixed subgroups of Argentinian and British students and each one had between two and three Skype conversations which were recorded and uploaded to the wiki; each conversation was usually between 1 and 2 hours, sometimes more. There were also the written products: collaborative leaflets or posters; songs, videos, drawings, PowerPoint presentations, surveys and reflection logs. The Argentinian students also completed the AIE (Byram et al., 2009). The AIE is a document which helps users to focus on a particular encounter with 'another' - in this case the students from the British university - and to analyse it by answering a sequence of questions based on a theory of intercultural competence and citizenship.

The data were all qualitative and were analysed following the guidelines and procedures in Corbin and Strauss (2008), De Costa (2014), Hatch (2002) and Cohen, Manion, and Morrison (2007), in particular using content analysis. Confidentiality and ethical issues were addressed and students signed informed consent forms to allow disclosure of their productions, with pseudonyms. The data were analysed from a number of perspectives, but the focus here will be on the Argentinian students and the two crucial matters of identification and criticality leading to action in the community.

\section{Transnational identifications}

Allport's conditions for creation of new group identities include, as we saw above, cooperation on a joint activity. As the Argentinian students worked on the collaborative design of a leaflet with their British partners, they began to develop an identification with the group as a transnational entity. The first indication of this is in the use of first person plural forms (italicised in the extract):

\footnotetext{
ARG: ¿Podemos usar unas de esas no? ( . . . podemos usar la segunda, la que dice 'detrás de la pantalla la realidad, boicoteo de la dictadura' y que hay una imagen de un militar apuntándole en la nuca a un hombre.

ENG: Sí. ¿Esta?

ARG: A ver ... claro sí esa. ¿Te parece que podríamos usar esa?

(Skype conversation, Group 2)

[ARG: We can use one of those [pictures], right? ( ... ) we can use the second, the one that says 'behind the screen, reality, boycott to dictatorship' and there is an image of a military pointing a gun at a man's neck.

ENG: Yes. This one?

ARG: Let me see ... sure, yes, that one. Do you think we could use that one?]
}

Later, the AIE provided an opportunity for meta-reflection, and one Argentinian student in the group from which the above data are taken said that she felt they became international peers - we did not use the term transnational with students - and that the international perspective allowed her to question her existing ideas:

I think my peers and I were international peers since we were all completely committed to do this project and we contributed with what we knew or investigated more. We divided the tasks and we all did it on time and with great enthusiasm. I found myself wanting to know more 
about [name]'s culture and points of view. (Andrea, Autobiography of Intercultural Encounters, emphasis added)

Again the use of the first person plural pronoun is significant. Sometimes it includes the whole mixed group ('we were all completely committed').

The collaborative leaflets also show this transnational identification. One group of students designed a poster comparing the World Cup in Argentina with the Hillsborough disaster in the UK, when many people were killed in an overcrowded stadium, a disaster which has since been blamed on the authorities. They juxtaposed images of both tragedies with a call for justice illustrated by the photographs ('Justice' in the case of the Hillsborough disaster; and 'Aparición con vida' -'Appear alive' in the dictatorship). They closed the leaflet with this message:

As a conclusion, we believe that the media has a major role in every community. Nevertheless, we have to be aware of the impact it has on people's opinions and ideologies. The media won't always tell the truth, and because of this we have to watch out as things may not always be what they seem.

The transnational identification is revealed by the use of the first-person plural pronoun 'we': 'we believe that ...', and also in the process of comparison. Expressions such as 'because of this we have to watch out'; 'things may not always be what they seem' are the basis for the social actions listed earlier. There is a collective call to beware of the media ('we have to be aware of'; 'we have to watch out') in the midst of the call for justice mentioned before.

Another indicator of group identification can be seen in the creation of a shared narrative about the events of the dictatorship. Here it is evident that the British students are attempting to empathise with the Argentinians, and in the following extract two Argentinian students explain the role of personal stories and memories in people's experiences, and how this goes beyond the history teaching that the British student expected:

ENG: Is this something you learn about in history?

ARG1: Yeah, we generally learn it in school, but it's not as deep as ... I don't know why, but ...

ARG2: Maybe we learn more from our parents, from their experience, from em, for example, I don't know, my grandpa who has a particular experience about that time, maybe you learn that way more than in school.

ARG1: Everybody here has some kind of connection with that period in our country, so you have stories around, is more likely to learn about that, that way.

(Skype conversation, Group 7, emphasis added)

Although the focus here, and among the students themselves, was more on the Argentinian students, the extract below shows that learning about dictatorship from personal stories happened also among the British students. Such stories, shared in the Skype conversations, brought the group together in the creation of a collective narrative albeit one which affects the Argentinian students most:

ENG: I asked my mum when she was younger, if she knew anything about the dictatorship and if the news had reached England. And she just said that people in England knew that bad things were happening in Argentina but they didn't know what they were.

(...) 


\begin{abstract}
ARG1: I actually can't remember the first I time I heard about this, but fortunately it was something that we talked about at home, usually. ( ... ) In my case, my dad is from the same town as me, but he was here in La Plata studying, and well, he really ... not suffered but, went through the whole period here, he was in fact taken into custody and held in prison for two days, because he was in a party and the police burst in since someone had informed them about a peronist chanting in that party, which my dad says it was a lie. And even if they were singing for Perón, I mean, people should not be taken away because of it. (...) I know my dad wasn't, I don't know about his friends, but I think most of them weren't involved in any kind of political group that was fighting for democracy. They were just young people enjoying the fact that one of them had just graduated from college, they were celebrating. Well, that's my personal experience.
\end{abstract}

(Skype conversation, Group 14, emphasis added)

de Groot, Goodson and Veugelers use the term 'citizenship narrative' and we too found the students involved in a 'sense of democratic engagement' (2014, p. 271). What we see in this conversation is each contributing a personal element from their own family, 'asked my mum', 'it was something we talked about at home'. Together with others in this conversation, they create a transnational and group-owned narrative which becomes a foundation for their criticality and community action.

\title{
Criticality
}

The stories which students told also contained evidence of the criticality which was a crucial aim of the project. In the previous extract, there is first the critique within the family narrative 'my dad says it was a lie' and then the student's own critique 'I mean people should not be taken away because of it'. Second, returning to the second leaflet about the Hillsborough disaster described above, we can see realisations of criticality applied to the third domain in Barnett's theory: world. The comments about the need to be aware of manipulation by the media indicate that students here reach the levels of critical skills and reflexivity. Furthermore, the leaflet itself is an example of the highest level of criticality, critique-in-action. The awareness-raising leaflet is intended to have an impact on people in the local community and includes an explicit call for justice ('Justice', 'Aparición con vida').

In her AIE, one Argentinian student narrated the story of one of the disappeared. The comments highlighted in italics show how the student's responses to the AIE questions led her to analysis and reflection. She is describing a photograph from a magazine of the time:

The photograph was published in a magazine with an article titled 'Los hijos del terror' [The children of terror]. This magazine, called Somos, was a big supporter of the military dictatorship, and they frequently posted this kind of articles, full of lies about what the situation was with the 'subversives'. In this case, it narrates the story of a child who was supposedly 'abandoned' by her activist parents.

(... I I find it appalling that someone would use this child's tragic story to keep feeding the public lies in order to cover up the militaries' crimes.

( ... )

The girl, who was three years old, was living in Uruguay with her parents when they were abducted or murdered by Argentines and Uruguayan military forces. That picture was taken before the girl was given to her grandmother (so it was a lie that no one had claimed her), in order to stage the story of an abandoned child in magazines such as Somos, Para Ti and Gente.

(Karina, Autobiography of Intercultural Encounters, emphasis added) 
Karina's AIE thus shows her applying critical skills to critique the media (the domain 'world') and to conclude that there was manipulation ('to stage the story of ... '). There is also evidence of her challenging what have been 'common sense' assumptions (that nobody claimed the little girl).

The first leaflet presented above, which included the mothers' white scarf, also provides evidence of criticality. In the first panel of the leaflet, the students wrote:

Argentina's bittersweet win

The 1978 FIFA World Cup was held in Argentina between 1 and 25 June. This country won the Football Cup for the first time and the official match ball was the Adidas Tango. Argentina's victory was a pivotal moment for soccer ardent Argentinian fans, but it also represented the worst of times for a nation trapped in the vise of dictatorship. The Videla Junta were planning to wipe the country clean of its image of violence and devastation; they wanted to show the world its capacity to regain itself. In this sense, the World Cup was used as a strategy to wash the faces of the murderers and hide the signs of political dissent and repression.

A critical stance permeates the leaflet and is revealed by the use of expressions such as 'bittersweet', 'the worst of times', 'a nation trapped in the vise', 'wipe clean', 'hide'. Here again the domain is 'world' and they have used their critical skills to reveal, initially to themselves, what was happening beneath the surface, 'the world cup was used as a strategy'. The phase of critical analysis of their own assumed 'knowledge' took place through the Skype conversations that this group held. In producing the leaflet, the comparing and contrasting (of the soccer fans and the military Junta; of Argentina and the world) are part of their approach to making others see the strategy they have uncovered. By making the leaflet public - in the civic action described in more detail below - they attempted to change assumptions and accepted perceptions of the World Cup in other people's memory. By taking their leaflet into the public domain and engaging with other people, they begin to reach Barnett's highest level of criticality in the domain 'world'.

Finally, we must note the significance of the outsider and insider perspectives. In her AIE, Andrea said of one of her British partners:

Also, he was eager to help us as many ways he could. I wouldńt have questioned myself about my ideas or points of view if I hadńt have the companionship of a person who saw the Argentinian Dictatorship from the outside.

This awareness of two perspectives within the same group and its effect on what had been taken for granted until that point reveals the value of a comparative study and of the interaction of the two groups. It leads to the critical thinking and the reflection on one's understanding in the 'knowledge domain' of Barnett's framework.

\section{Civic action - action in the community}

Their reflections and critical evaluation led groups to dwell upon the importance of knowing about this period as a springboard to improving the future, not their own future but rather a more distant perspective that involved them in thinking about the collective well-being of future generations. This disinterested wish to improve the future for others one does not know is important in citizenship education, encompasses a dimension of justice in education (Budd, 2013) and echoes current discourses of education on hope (Andrews, 2010; Webb, 2010). 
In this project, it grew in part out of the sharing of personal stories as well as the building of collective stories about the dictatorship period during the Skype conversations mentioned earlier. There is first the stage of what 'we' have to remember, where 'we' can be both the students as individuals and the (national) groups to which they belong. As is evident from the extract which follows, it is not just a matter of commemoration, 'important to know what happened', but knowledge of the past is important for the future, 'avoid happening again', and the way to ensure that the past influences the future is through teaching, 'teaching children':

ARG1: I think it's important to know what happened in the past, and to avoiding happening again.

ENG: Yeah, yeah, of course.

( ... )

ARG: I think that we don't have to [must not - author] forget ( ... ) it would help us to avoid to commit the same, em, disaster again.

ENG: Yeah, it would [ ... ]. I think by teaching children [ ... ] schools, it would like ... It makes everybody aware. So, and everybody would be really shocked by it.

(Skype conversation, Group 3, emphasis added)

This wish to raise awareness of the atrocities of the dictatorship period illustrates a perspective involving a 'transformatory critique' of the 'world', Barnett's 'critique-in-action', and was the basis of the actions in the community that the Argentinian students carried out. The actions were varied as is evident from the following selection:

- they talked to family and friends and interviewed a neighbour (https://www.youtube. com/watch? $v=$ wrqDSiv28_s\&feature=youtu.be);

- some talked to passers-by in Plaza San Martín (San Martin Square) in La Plata, which is a site of political struggle and demonstrations since it is faced by the House of Government and the House of Representatives (http://www.youtube.com/watch?v= kJXLOOiexks\&feature=youtu.be);

- some gave a talk and shared posters and information with university students at the local School of Medicine (http://www.slideshare.net/gaiacoboni/1978-fwc-at-schoolof-medicine) and another group did the same with students from various courses of studies (http://www.slideshare.net/gaiacoboni/aic-1978-football-world-cup);

- one travelled $100 \mathrm{~km}$ to work with student teachers at Instituto Superior de Formación Docente y Técnica No. 90, a teacher training college in the city of Verónica, on how to teach this historical period with primary school students;

- another travelled $500 \mathrm{~km}$ to a city called Lincoln to interview a 95-year-old man whose son had disappeared (http://www.slideshare.net/gaiacoboni/aic-1978-fbwc-in-lincoln);

- one student contributed a drawing made in one of the groups to the local Museo de Arte y Memoria (http://prezi.com/xtkdjpsseqyi/action-in-the-community/);

- some were interviewed by social communication students at the university radio station (http://www.slideshare.net/gaiacoboni/socializacin-del-proyecto);

- others produced a report on an artistic movement called Baldosas por la Memoria, which sets a tile in front of houses from where people were taken; each tile has the name of a victim and the date of their kidnapping;

- inspired by the group visit to the museum Museo de Arte y Memoria in La Plata, one group recorded a tour of the Casa Mariani - Teruggi, a house from which a couple 
and their children were taken and have never been seen since. The house has been preserved as a museum and the students interviewed the museum guides (https:// www.youtube.com/watch? $=$ MWTWOHsP_WE);

- finally, others carried out a survey in the city to find out what young people knew about the dictatorship (http://prezi.com/6dovsueqd7a_/accion-en-la-comunidad/? utm_campaign=share\&utm_medium=copy).

In all these examples, students engaged with people and tried to change things in their own community, which in fact ranged from the university to the city and beyond. It is however also noteworthy that they wanted to make their actions more widely known through YouTube postings and this too constitutes an action - but this time in a much wider community.

\section{Conclusion}

To guide our analysis we started with the research question:

Does a course which combines language teaching and citizenship education lead learners to identification with a transnational community, to critical engagement with the communities in which they live, and to action in their communities?

We have seen that there is evidence that some learners did identify with their transnational community and some learners became involved in their communities. As primarily a project to test the implementation of concepts and theories, rather than one which charted in quantitative or qualitative data the learning achieved by individual learners, the findings were satisfactory in showing that teachers and students could change the focus of their lessons. For it is important that this intercultural citizenship project was undertaken in regular undergraduate courses in both universities, which until then had had no civic component at all. The demands on students were substantial, as is evident from the written logs students kept. For instance, one Argentinian group prepared a presentation at a community centre in the slums of a nearby town called Ensenada (http://youtu.be/r3UAsZU9fdo) and one student wrote a description and a conclusion which defined clearly the sense of responsibility she and others felt:

Well, I work as a volunteer in the neighbourhood called San José, Ensenada. Actually it is a 'villa de emergencia' (I looked for a translation, but I couldn't find one. I don't know if there's any), and I work with people who don't know how to read or write. There is a high rate of illiteracy in that neighbourhood. The other students in my group (Claudio, Pablo and Melisa) knew about my volunteer work so we thought it was a good idea to inform people about what happened 37 years ago. We prepared some photographs to show them (most of the pictures were taken when we visited Museo de Arte y Memoria), a song written by León Gieco, a poster and a documentary which explained what happened at the time. We also thought that every resource we had at hand was very useful because most of the people who attended our talk didn't know what happened during the last dictatorship. In fact, only one person knew almost everything about it because she's 71 years-old and had some friends who disappeared. During this experience, we have learnt that in spite of the fact that we live in democracy, there seems to be a lot of people who still don't know about what happened during the darkest period of Argentinian history. If the media and the government don't fulfil their duty and don't inform the population about it, then we feel it is our job to let them know. (Pamela, Reflection log, emphasis added) 
Another example comes from a group which highlighted their sense of commitment and responsibility towards others in their decision to undertake their specific civic action, despite the difficulties which they comment on in the first sentence:

Doing this project was not easy, that's for sure. It took us quite some time to finish it and hours of uncertainty thinking if we could put our ideas on paper. But when we saw them published on the walls, we forgot about all that and couldn't stop thinking if those ideas could become more than just words and awake something on whoever reads them. As we were publishing them, some girls asked us about the posters we were publishing. And we explained briefly what we had done. From the moment we talked with the girls and they became interested in what we were doing, we felt that everything we had been through, had been worth it. (Reflection $\log$, Group 9, emphasis added)

To make demands that students commit much of their time beyond what they would usually have done for the language classes, and to expect them to work with such uncertainty raise important questions about the relationship of universities to their communities and the wider world. The project described here is what Barnett (2011) would categorise as 'the developmental university', producing knowledge in and for the world and intent on improving the world. It can also be compared with the ambitions of the Talloires network of universities whose vision statement - which we were not aware of at the beginning of our work - includes the notion fundamental to our project, 'civic engagement':

We believe that higher education institutions do not exist in isolation from society, nor from the communities in which they are located. The Talloires Network envisions universities around the world as a vibrant and dynamic force in their societies, incorporating civic engagement and community service into their research and teaching mission.

http://talloiresnetwork.tufts.edu/who-we-are/

This conceptualisation of Higher Education is what Brady (2012, p. 343) refers to as 'the moral reconstruction of universities', 'the restoration of an "academic community" founded on "higher moral purpose", and our project attempted to realise this in a small-scale and modest way.

\section{Acknowledgements}

The authors are extremely grateful to Dr Leticia Yulita (University of East Anglia), researcher and teacher in charge of this project in the United Kingdom, and to Prof. Gabriela Iacoboni, teacher in Argentina. Also the authors' deep appreciation goes to the students in Argentina and Britain who took part in this project.

\section{Disclosure statement}

No potential conflict of interest was reported by the authors.

\section{Note}

1. We are aware that the debate about the functions of teaching language, particularly English, as lingua franca or international language, and about the educational as well as instrumental value of such teaching is far from over, but we do not have space to pursue this further here. 


\section{References}

Allport, G. (1954/1979). The nature of prejudice. Reading, MA: Addison-Wesley.

Andrews, P. (2010). Hope and the many discourses of education. Cambridge Journal of Education, 40, 323-326.

Arthur, J., Davies, I., \& Hahn, C. (2008). The Sage handbook of education for citizenship and democracy. Los Angeles, CA: Sage.

Barrett, M. (2012). The PIDOP Project: An overview [Unpublished report]. Retrieved from http:// www.fahs.surrey.ac.uk/pidop/

Barnett, R. (1997). Higher education: A critical business. London: Open University Press.

Barnett, R. (2011). Being a university. London: Routledge.

Block, D. (2007). Second language identities. London: Continuum.

Brady, N. (2012). From 'moral loss' to 'moral reconstruction'? A critique of ethical perspectives on challenging the neoliberal hegemony in UK universities in the 21 st century. Oxford Review of Education, 38, 343-355.

Bredella, L. (2010). Trans- oder Interkulturalität als Bildungsziel des Fremdsprachenlehrens und -lernens? ForumSprache, 4, 21-43. Retrieved from https://www.hueber.de/sixcms/media.php/ 36/ForumSprache 04_2010 978-3-19-186100-1.pdf

Budd, J. (2013). Informational education: Creating an understanding of justice. Education, Citizenship and Social Justice, 8, 17-28.

Byram, M. (1997). Teaching and assessing intercultural communicative competence. Clevedon: Multilingual Matters.

Byram, M. (2008). From foreign language education to education for intercultural citizenship. Clevedon: Multilingual Matters.

Byram, M. (2012). Conceptualizing intercultural (communicative) competence and intercultural citizenship. In J. Jackson (Ed.), Routledge handbook of language and intercultural communication (pp. 85-97). Abingdon: Routledge.

Byram, M., Barrett, M., Ipgrave, J., Jackson, R., Méndez García, M. C., ... Leclercq, J. M. (2009). Autobiography of intercultural encounters. Context, concepts and theories. Strasbourg: Council of Europe, Language Policy Division. Retrieved from coe.int/lang-autobiography

Byram, M., Golubeva, I., Han, H., \& Wagner, M., (Eds.). (in press). Education for intercultural citizenship - Principles in practice. Clevedon: Multilingual Matters.

Canagarajah, S. (2005). Dilemmas in planning English/vernacular relations in postcolonial communities. Journal of Sociolinguistics, 9, 418-447.

Center for Civic Education. (2008). Project citizen textbook level 1. Calabasas, CA: Author.

Cohen, L., Manion, L., \& Morrison, K. (2007). Research methods in education (6th ed). London: Routledge.

Corbin, J., \& Strauss, A. (2008). Basics of qualitative research: Techniques and procedures for developing grounded theory (3rd ed.) Thousand Oaks, CA: Sage.

Coyle, D. (2007). Content and language integrated learning: Towards a connected research agenda for CLIL pedagogies. International Journal of Bilingual Education and Bilingualism, 10, 543-562.

De Costa, P. (2014). Making ethical decisions in an ethnographic study. TESOL Quarterly, 48, 413-422.

Ellemers, N. (2012). The group self. Science, 336, 848-852.

Gellner, E. (1987). Culture, identity and politics. Cambridge: Cambridge University Press.

de Groot, I., Goodson, I., \& Veugelers, W. (2014). Dutch adolescents' narratives about democracy: 'I know what democracy means, but not what it means to me'. Cambridge Journal of Education, 44, 271-292.

Hafner, C. A., Chik, A., \& Jones, R. H. (2013). Engaging with digital literacies in TESOL. TESOL Quarterly, 47, 812-815.

Hatch, A. (2002). Doing qualitative research in education settings. Albany: State University of New York Press.

Hobsbawm, E. J. (1992). Nations and nationalism since 1780. Cambridge: Cambridge University Press.

Holliday, A. (2006). Native-speakerism. ELT Journal, 60, 385-387.

Houghton, S. A., \& Rivers, D. (Eds.). (2013). Native-speakerism in Japan. Intergroup dynamics in foreign language education. Bristol: Multilingual Matters.

Liddicoat, A., \& Scarino, A. (2013). Intercultural language teaching and learning. West Sussex: Wiley \& Sons. 
Livingstone, S. (2012). Critical reflections on the benefits of ICT in education. Oxford Review of Education, 38, 9-24.

Norton, B. (2000). Identity and language learning: Gender, ethnicity and educational change. London: Longman/Pearson Education.

Norton, B., \& Toohey, K. (2011). Identity, language learning, and social change. Language Teaching, $44,412-446$.

Osler, A. (2012). Citizenship education and diversity. In J. A. Banks (Ed.), Encyclopedia of diversity in education (Vol. 1, pp. 353-361). Los Angeles, CA: Sage.

Osler, A., \& Starkey, H. (2006). Education for democratic citizenship: A review of research, policy and practice 1995-2005. Research Papers in Education, 21, 433-466.

Porto, M. (2014). Intercultural citizenship education in an EFL online project in Argentina. Language and Intercultural Communication, 14(2), 245-261.

Qualifications and Curriculum Authority (The Crick Report). (1996). Education for citizenship and the teaching of democracy in schools. London: Qualifications and Curriculum Authority.

Risager, K. (2007). Language and culture pedagogy. From a national to a transnational paradigm. Clevedon: Multilingual Matters.

Ros i Solé, C. (2004). Autobiographical accounts of L2 identity construction in Chicano literature. Language and Intercultural Communication, 4, 229-241.

Ros i Solé, C. (2007). Language learners' sociocultural positions in the L2: A narrative approach. Language and Intercultural Communication, 7, 203-216.

Ros i Solé, C. (2013). Cosmopolitan speakers and their cultural cartographies. The Language Learning Journal, 41(3), 326-339.

Ros i Solé, C., \& Fenoulhet, J. (2011). Language learning itineraries of the twenty-first century. In J. Fenoulhet \& C. Ros i Solé (Eds.), Mobility and localisation in language learning. A view from languages of the wider world (pp. 3-28). Bern: International Academic Publishers.

Tajfel, H. (1982). Social psychology of intergroup relations. Annual Review of Psychology, 33, 1-39.

Tsui, A. (2007). Complexities of identity formation: A narrative inquiry of an EFL teacher. TESOL Quarterly, 41, 657-680.

Warschauer, M., Zheng, B., \& Park, Y. (2013). New ways of connecting reading and writing. TESOL Quarterly, 47, 825-830.

Webb, D. (2010). Paulo Freire and 'the need for a kind of education in hope'. Cambridge Journal of Education, 40, 327-339. 